\title{
KEBEBASAN INFORMASI KALANGAN MILENIAL DALAM BERMEDIA SOSIAL
}

\author{
Endang Fatmawati \\ Universitas Diponegoro, Semarang \\ endangfatmawati@live.undip.ac.id
}

\begin{abstract}
ABSTRAK
Media digital telah merubah eksistensi kalangan milenial dalam berinteraksi dan berkomunikasi. Semua bisa dilakukan dengan lebih cepat, mudah, dan murah. Perilaku mengakses informasi bagi kalangan milenial selalu lekat dengan perangkat teknologi digital. Kemampuan internet dalam menjangkau secara verbal dan visual, menjadikan internet mempunyai peran sangat penting dalam komunikasi. Gaya hidup menggunakan smartphone menjadi potret kalangan milenial di era media sosial. Kebebasan informasi bagi kalangan milenial perlu diimbangi dengan kompetensi literasi digital, pengetahuan normatif, dan kecerdasan intelektual dalam menggunakan media sosial.
\end{abstract}

Kata kunci: milenial, media sosial, pengguna internet, kebebasan informasi.

\section{PENDAHULUAN}

Internet bagi kalangan milenial sudah tidak terpisahkan lagi. Internet tidak hanya hadir untuk mengakomodir kebutuhannya akan informasi tetapi juga menjadi ruang interaksi sosial yang lebih besar. Bahkan era media sosial telah semakin mendukung perilaku kalangan milenial dalam berinternet. Milenial dalam keseharian selalu lekat dengan perangkat digital. Jadi hanya bermodal internet, milenial memiliki kebebasan informasi. Hal ini artinya bisa dengan mudah mengunggah informasi, mengunduh, menyebarkan, serta dapat berselancar menembus dan bebas menjangkau ke belahan dunia manapun dan kapanpun. Perilaku kalangan milenial yang cenderung serba instan membuat mereka kadang tidak memperhatikan keakuratan dan kredibilitas informasi yang diperoleh. Era global membuat kalangan milenial cenderung lebih bebas dalam berekspresi melalui media sosial. Hal inilah terjadi proses multidimensi dengan fenomena baru yang jauh lebih kompleks. Dalam aktivitasnya, kalangan milenial mengkonsumsi gawai dan aksesoris perangkat digital lainnya. Mereka memilih produk perangkat digital dan memiliki cara tertentu dalam menggunakan atau mengoperasikan gawainya. Dalam proses untuk membentuk identitas diri sebagai kalangan milenial, mereka selalu mengkonsumsi gawai dalam aktivitasnya. Dalam konteks inilah permasalahan terkadang muncul terkait masifnya kebebasan informasi. Tidak heran jika muncul sisi negatif dari bebasnya mengakses informasi, oleh sebab itu fenomena yang terjadi di lapangan membutuhkan strategi pemecahan masalah. 


\section{TINJAUAN PUSTAKA}

\section{Kalangan milenial}

Menurut (Tapscott, 2009) bahwa siswa digital mengharapkan kecepatan, tidak hanya video game saja, tetapi respon instan. Artinya permainan video game bisa memberi umpan balik insta $\mathrm{n}$ dan google dapat menjawab pertanyaan dalam hitungan detik. Selanjutnya (Jones dan Shao, 2011) juga menyebutkan ada perubahan tajam dalam karakteristik generasi baru yang menjadi agen perubahan lebih lanjut. Kehadiran teknologi digital begitu cepat dan meluas. Kalangan milenial tidak dapat dielakkan akan dikepung oleh media digital. (Young, 1998) disebutkan bahwa tingkat keadiktifan seseorang terhadap internet, terbagi dalam kategori internet digunakan pada jangka waktu lama tetapi masih memiliki kontrol dalam penggunaan (mild), internet menjadi penting dalam kehidupan tetapi tidak menjadi utama (moderate), dan tidak bisa hidup tanpa adanya internet (severe), dalam konteks ini kondisi kalangan milenial tergolong severe.

Perpustakaan memiliki relevansi dengan pemustaka milenial, jika dikontekstualisasikan pada pemustaka, maka lahirnya generasi pemustaka yang tergolong kalangan milenial berdampak pada transformasi layanan perpustakaan menuju pelayanan mandiri. Sebagaimana pendapat (Gallacher, 1999) bahwa faktor perubahan yang paling berpengaruh di perpustakaan adalah terkait perkembangan teknologi ke arah layanan mandiri (self service technologies). Gallacher dalam (Brine, 2009) menawarkan panduan yang sangat baik untuk membantu para pimpinan perpustakaan dalam memahami, merencanakan, dan mengelola sebuah perubahan. Teknologi digital yang semakin canggih diterapkan di perpustakaan, semakin membuat kalangan milenial semakin memiliki peluang besar untuk memanfaatkannya. Pemustaka milenial tumbuh dalam pergolakan budaya, terlebih era digital yang membuat informasi sedemikian masif berkelindan di sekelilingnya, mereka sangat kenyang dengan berbagai iklan lifestyle seperti halnya produk smartphone (contoh: samsung, apple, oppo, sony, iphone, xiaomi, realme, vivi, huawei, asus, dan lain sebagainya). Merebaknya games online yang memiliki banyak pilihan, juga membuat milenial kecanduan dan menjadi betah berlama-lama untuk bermain.

Terkait dengan bahasan internet dikalangan milenial, dapat dijelaskan bahwa selain memudahkan milenial untuk berkomunikasi, internet juga membawa dampak munculnya anonimitas. Kalangan milenial ketika beraktivitas di internet bisa melakukan privasi dengan cara tidak menunjukkan identitas atau tidak menyebutkan nama. Salah satu karakteristik dari kalangan milenial adalah memiliki kecenderungan menganut budaya konsumtif, sehingga dapat dikatakan bahwa mengkonsumsi sesuatu karena termotivasi untuk mengikuti trend yang sedang berkembang saja, sehingga persoalan dari segi fungsi menjadi terabaikan. Budaya konsumtif tersebut muncul karena perubahan makna konsumsi yang dipengaruhi oleh adanya perubahan sikap, pandangan, dan pola hidup konsumtif. Aktivitas untuk berselancar di dunia maya menjadi salah satu rutinitas yang banyak dilakukan oleh kalangan milenial, kehidupan mereka seperti dimonopoli oleh kedigdayaan teknologi yang berdampak relasi antar manusia berubah menjadi relasi kebendaan. Pemustaka milenial sebagai objek pengguna internet idealnya mampu mengelola kecerdasan intelektual dan memiliki kompetensi literasi digital, selain itu milenial juga harus memiliki keterampilan untuk menghalau tantangan untuk menghadapi permasalahan kehidupan mereka yang semakin kompleks. 
Internet mengubah gaya hidup kalangan milenial mulai dari bentuk ruang dan waktu di dalam internet tidak lagi sama dengan dunia nyata, karena penggunanya dapat melakukannya secara realtime. Menurut (Holmes, 2005) mengemukakan bahwa keberadaan internet yang dikatakan sebagai Computer Mediated Communication (CMC) telah memediasi sehingga mereka hanya perlu koneksi internet untuk saling terhubung dalam dunia sosial yang baru. Interaksi virtual ditunjukkan dengan hal yang terkadang tidak ada dalam kenyataan, namun sesuatu yang virtual tersebut bisa menjadi nyata sekalipun tidak berwujud secara aktual.

Kalangan milenial yang dalam kehidupannya tidak bisa lepas dari internet, akan membuka peluang besar bagi mereka untuk menjadi manusia yang semakin lihai dan sangat paham dalam menggunakan teknologi digital. Semakin mudahnya milenial mengakses informasi, maka akan mempermudah proses berjalannya simulasi dalam bentuk dunia maya. Menurut Baudrillard (dalam Haryatmoko, 2016), simulasi merupakan sebuah representasi dari sebuah obyek yang justru mengganti objek yang direpresentasikannya. Milenial berpeluang besar untuk selalu tampil eksis melalui cyberspace. Eksistensi menunjukkan keberadaan dan situasi yang mengarahkan kalangan milenial pada keberadaan autentik. (Thompson, 2010) menjelaskan keberadaan autentik berarti menjadi dirinya sendiri atau mengambil tanggung jawab untuk menjadi dirinya sendiri dengan menyeleksi kemampuan yang dimiliki.

\section{Kebebasan Informasi}

Kebebasan informasi kalangan milenial perlu diimbangi dengan bekal kompetensi literasi digital. Hal ini meliputi pengetahuan, keterampilan, maupun sikap untuk memahami dan menggunakan informasi yang diakses melalui perangkat komputer. Seiring dengan upaya kalangan milenial meningkatkan kompetensi literasi digital, maka dalam pelaksanaannya harus diimbangi dengan pengetahuan secara normatif terkait dengan peraturan hukum dan regulasinya. Masalah kebebasan informasi dikaitkan dengan tinjauan normatif terkait dengan pengetahuan tentang konvensi, peraturan, norma, dan aturan perundangan lainnya yang menjadi pijakan dalam bermedia sosial.

Sisi positif media sosial antara lain sebagai sarana berkomunikasi, berinteraksi, dan berbagi informasi untuk membangun jaringan sosial secara luas, dapat dikatakan bahwa dengan media sosial maka kenyataannya pengguna bisa bebas sebagai produsen dan konsumen informasi dengan tanpa intervensi. Kalangan milenial sebaiknya juga mengetahui produk hukum seperti halnya Undang-Undang RI Nomor 14 Tahun 2008 tentang Keterbukaan Informasi Publik. Rambu dan bentuk jeratan regulasi dibutuhkan agar pengguna taat asas dan bersikap lebih bijak dalam bermedia sosial. Pemerintah melalui Kemkominfo juga tegas menghadapi informasi yang meresahkan masyarakat, misalnya: menggulirkan peraturan sebagai payung hukum dalam kebebasan berinformasi, memblokir situs-situs berbahaya, penertiban situs secara maya. Selain itu, juga gencar dalam aksi menjerat atau menghukum kepada pelaku kejahatan di dunia maya. Untuk pencegahan meluasnya akses negatif dan merajalelanya oknum yang tidak bertanggung jawab maka tindakan tegas pemblokiran yang dilakukan oleh pemerintah menjadi efektif.

Kebijakan pemerintah dalam menangani beredarnya hoaks semakin serius, terutama dalam memproteksi ruang siber dari ancaman proliferasi. Secara normatif, hal ini terlihat dari 
revisi UU RI Nomor 11 Tahun 2011, yang diubah menjadi UU RI Nomor 19 Tahun 2016. Ada sanksi hukum untuk perbuatan yang dilarang, baik pidana penjara maupun denda. Hal ini misalnya terkait sanksi hukum pada pasal 27 (mendistribusikan, mentransmisikan, membuat dapat diakses) dan seterusnya. Adanya tujuh poin penting yang mendasari perubahan Undang-Undang tersebut.

Awal mula UU RI No. 11 tahun 2008 disusun untuk mendukung pertumbuhan ekonomi digital dan e-commerce, namun seiring dengan pesatnya kemajuan TIK dan penggunaan media sosial, maka muncul berbagai permasalahan dalam pelaksanaannya. Berbagai polemik bermunculan, begitu juga merebaknya isu pro dan kontra terkait pasal di dalamnya yang mengancam kebebasan berekspresi pengguna media sosial. Kategori penggunanya berarti menggunakan internet baik melalui perangkat komputer pribadi, perangkat mobile pribadi, kedua-duanya, maupun melalui fasilitas lainnya.

Dampak kebebasan berinformasi bukan berarti tanpa persoalan, namun demikian juga muncul aneka kejahatan dengan motif tertentu, seperti halnya cyberfroud. Hal ini karena cepatnya penetrasi internet dan penggunaan aplikasi media sosial juga semakin tinggi. Kalangan milenial perlu memahami sejak dini berbagai payung hukum dan peraturan perundangan yang terkait dengan kebebasan informasi.

\section{Pengguna Internet}

Pandangan (Dijk, 2006), internet itu menyebabkan timbulnya suatu kondisi yaitu tidak adanya batasan waktu dan tempat (timeless and placeless) dalam komunikasi di masyarakat. Dalam perkembangannya pengguna internet dalam konteks di Indonesia ternyata telah menjadikan platform media sosial yang paling banyak dipakai. Majunya aspek Teknologi Informasi dan Komunikasi (TIK) mengindikasikan suatu kondisi dalam era revolusi industri. Kondisi ini membuat perilaku yang tidak mungkin lepas dari ketergantungan pada teknologi informasi. Informasi di era media sosial seperti ada di "ujung jari”.

Informasi kini menjadi kebutuhan pokok setiap orang. Pesatnya perkembangan media sosial, menjadi pemantik setiap orang untuk menjadi sumber berita/penyampai pesan (komunikator). Dari tahun ke tahun, pertumbuhan pengguna internet terus mengalami kenaikan yang signifikan. Pengguna internet yang dimaksud sebagaimana dalam survei (APJII, 2018) memiliki ciri khas, antara lain:

- Individu tersambung internet (dari dalam rumah atau dari tempat lain).

- Melalui perangkat (komputer, perangkat mobile, perangkat lain).

- Perangkat bisa milik sendiri atau bukan

\section{METODE PENELITIAN}

Dalam kajian ini penulis menggunakan metode studi literatur/studi pustaka, dimana metode ini penulis dapat membaca dan memahami berbagai macam sumber informasi baik cetak maupun sumber online, yang berupa thesis, skripsi, jurnal ilmiah yang berkaitan dengan kebebasan informasi kalangan milenial dalam bermedia sosial. Studi literatur ini sangat berguna dan bermanfaat bagi penulis karena penulis mampu mengetahui konsep-konsep secara detail dan membuat kerangka berfikir khususnya dalam hal mengatur dan memilih mana referensi yang relevan dengan kajian yang dibuat seperti yang dikatakan (Koentjaraningrat,1983). 


\section{PEMBAHASAN}

Data pengguna internet di Indonesia yang penulis sarikan dari data APJII, diketahui bahwa pada tahun 2014 (88,1 juta jiwa), tahun 2015 (110,2 juta jiwa), tahun 2016 (132,7 juta jiwa), serta tahun 2017 (143,26 juta jiwa). Pada tahun 2018 terus meningkat pesat sebesar 171,17 juta jiwa orang telah menggunakan internet. Realitas tahun 2018 berarti menunjukkan jumlah pengguna yang signifikan sebesar $64,8 \%$ (dari total jumlah populasi sebesar 264,16 juta orang). Dominasi pengguna internet terbanyak adalah di pulau Jawa yang jumlah penggunanya $55,7 \%$, selanjutnya untuk persentase kontribusi pengguna internet paling banyak yang tersebar di pulau Jawa adalah provinsi Jawa Barat yaitu sebesar 16,7\%.

Sisi lainnya terkait gaya hidup berbelanja online, bahwa data dari Indonesia Mobile Habit (JAKPAT.NET, 2017) masih menunjukkan kondisi penggunaan smartphone untuk keperluan belanja yang menduduki peringkat terakhir. Hasil survei (Data Reportal, 2020) digital pada Januari 2020, sudah mengalami kenaikan signifikan dengan posisi ketiga (66\%), dari data diatas menunjukkan era media sosial telah mempengaruhi perilaku pengguna internet di Indonesia untuk berbelanja online, ditambah dengan situasi pandemi wabah non alam Covid-19 dengan segala kebijakan pemerintah yang digulirkan. Kondisi pandemi memaksa masyarakat belanja dari rumah, sehingga secara tidak langsung turut menguatkan perilaku masyarakat dengan model berbelanja berbasis online. Terkait perilaku berbelanja online yang didukung pula dengan data (APJII, 2018) bahwa ada internet yang kontennya bersifat komersial dan sering dipakai dalam aktivitas membeli barang maupun berbagai jasa online seperti Shopee, Bukalapak, Lazada, kemudian disusul Tokopedia, sehingga dapat disimpulkan bahwa naiknya jumlah pengguna internet tiap tahun akan berbanding lurus dengan kenaikan pengguna media sosial.

Mengkritisi kondisi yang demikian, berarti internet sebetulnya merepresentasikan bagian potret gaya hidup masyarakat kita dancenderung konsumtif menggunakan internet untuk mengakses media sosial (seperti: komunikasi lewat pesan, mengisi waktu luang, menonton film/video, berbelanja online, dan yang lainnya, dengan demikian, internet yang memiliki sistem komunikasi terdesentralisasi mampu memfasilitasi terjadinya kesetaraan dalam posisi antar subyek yang berkomunikasi, sehingga tidak ada hierarki, jarak sosial, maupun pemusatan kontrol diantara subjek.

Media sosial dalam penggunaannya untuk komunikasi melalui pesan, menjadi makanan sehari-hari kalangan milenial. Penggunaan untuk kategori media sosial (Gambar 1) yang menempati porsi urutan kedua $(18,1 \%)$, setelah aktivitas media sosial yang digunakan untuk komunikasi lewat pesan $(24,7 \%)$. 


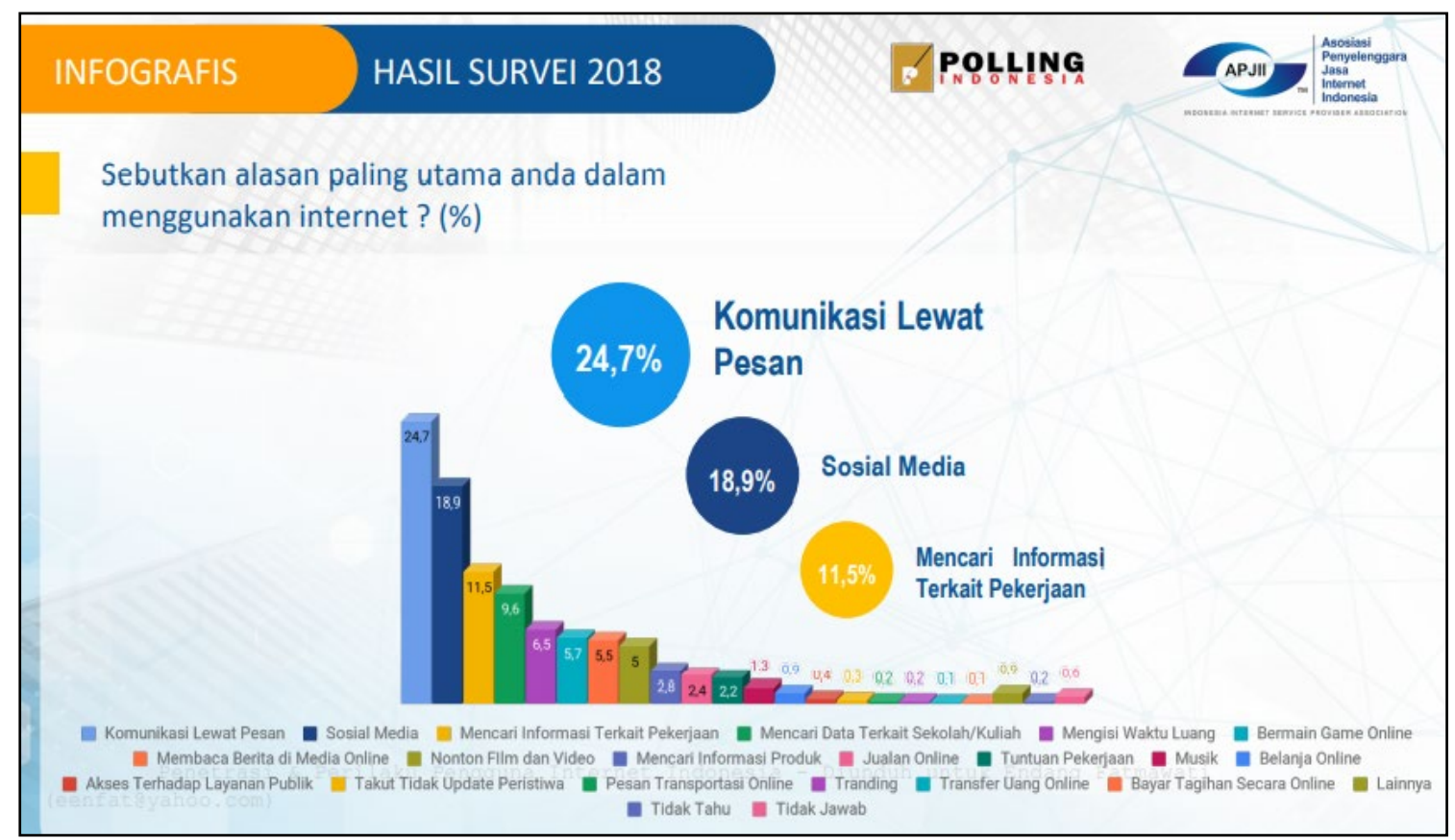

Gambar 1. Alasan Utama Menggunakan Internet

(Sumber: APJII, 2018)

Perpustakaan mengakomodir dengan menyediakan fasilitas pendukung untuk akses internet. Cara yang dilakukan masyarakat agar bisa terhubung dengan internet ada banyak sekali. Hal ini misalnya: dengan paket data/kuota dari operator seluler, memakai internet di rumah, pergi ke rumah teman/tetangga, memanfaatkan koneksi internet di sekolah/kampus, mendayagunakan wifi perpustakaan, menggunakan koneksi internet di kantor, memakai koneksi wifi di ruang publik, pergi ke kafe/restoran yang ada wifi, pergi ke warnet, maupun cara lainnya. Selanjutnya pada Gambar 2 terlihat penggunaan media sosial yang sangat beragam.

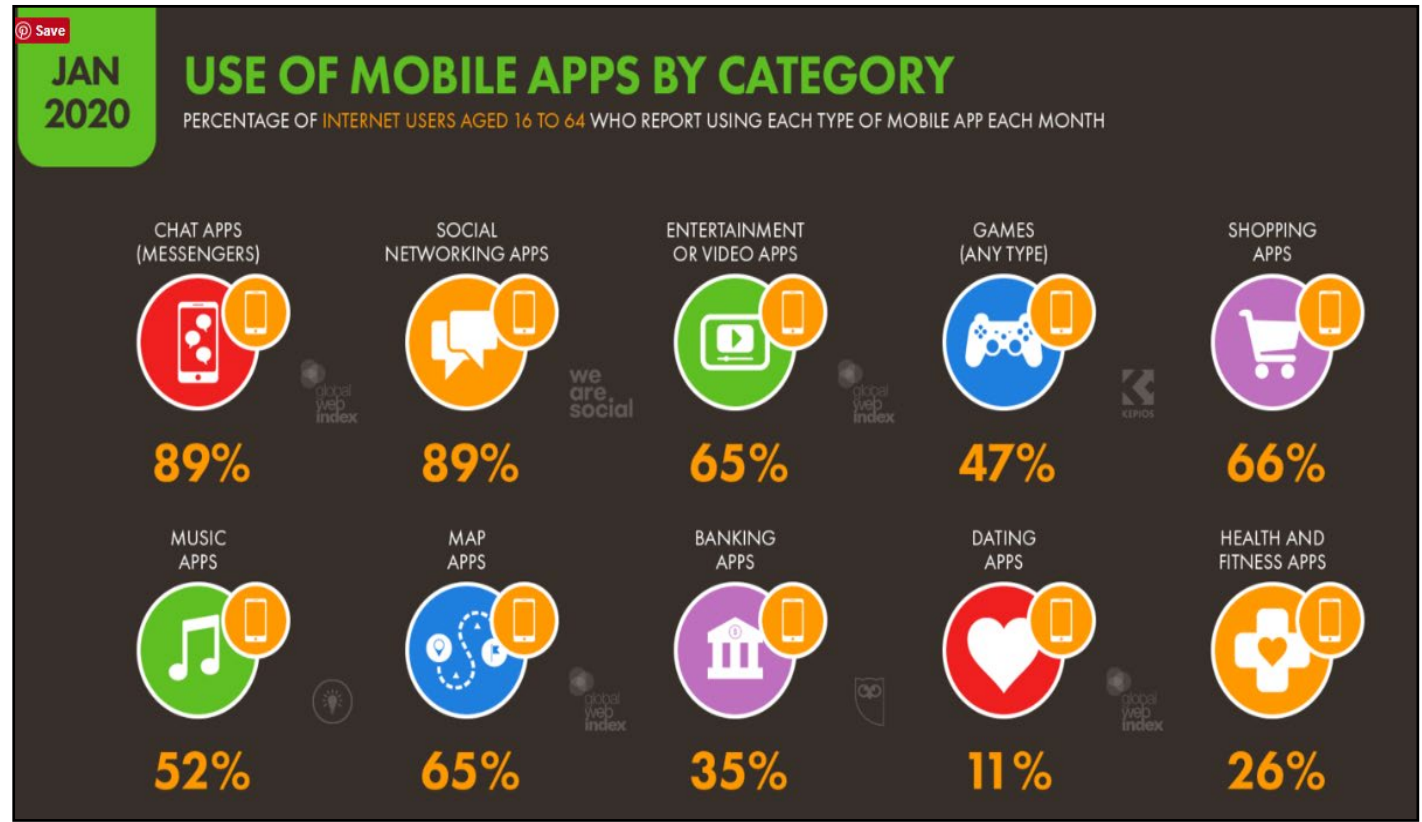

Gambar 2. Kategori Penggunaan Sosial Media

(Sumber: Data Reportal, 2020) 
Dari Gambar 2 nampak bahwa penggunaan smartphone untuk keperluan chat berada pada peringkat pertama, baru kemudian disusul dengan aktivitas lainnya. Kondisi ini tidak mengherankan karena data dari APJII pada tahun 2017 saja, sudah diketahui bahwa aktivitas chatting di media sosial menempati porsi tertinggi (89,35\%). Begitu pula terkait pemanfaatan internet bidang gaya hidup yang penggunaannya untuk kategori media sosial, menempati porsi tertinggi sebesar $87,13 \%$.

\section{Era Media Sosial}

Era media sosial berdampak pada perilaku kalangan milenial untuk selalu terhubung dengan internet, baik itu melalui perangkat komputer dekstop, komputer laptop, smartphone/ponsel, maupun tablet. Namun kenyataannya banyak yang menggunakan perangkat smartphone setiap harinya daripada perangkat lainnya. Hal ini didukung dengan data yang dilansir (APJII, 2018) bahwa setiap hari tersambung internet melalui perangkat smartphone sebesar 93,9\%.

Kalangan milenial harus bijak bermedsos, hal ini termasuk tidak mengunggah data pribadi secara virtual, karena suatu saat kemungkinan akan menjadi bumerang bagi diri kita sendiri sehingga segala sesuatu yang bersifat pribadi justru menjadi konsumsi publik. Adanya ruang bebas berupa privacy yang kemungkinan bisa diinvasi, sehingga harus berhati-hati karena dikhawatirkan ada oknum yang dengan sengaja memang memanfaatkannya dan perlu diwaspadai karena apapun yang dilakukan secara online sekalipun sudah dihapus maka tetap akan meninggalkan jejak.

Bagi kalangan milenial smartphone diera media sosial berperan penting dalam kehidupan sehari-hari, selain sebagai alat komunikasi, smartphone berperan sangat penting dalam keseharian bagi pengguna ponsel. Terkait waktu yang dihabiskan untuk menggunakannya, kebanyakan setelah bangun tidur maupun sebelum tidur. Penulis berpendapat bahwa perilaku laki-laki dan perempuan itu berbeda ketika menggunakan smartphone dalam kegiatan sehari-hari. Hal ini senada dengan survei yang telah dilakukan oleh JAKPAT Survey Report tahun 2019 terhadap 1007 responden. Salah satu hasilnya yaitu berbeda dalam menggunakan ponsel dari sisi perempuan dan laki-laki. Game seluler didominasi oleh laki-laki, sedangkan belanja online didominasi oleh perempuan.

Selanjutnya jejaring sosial yang terbanyak digunakan adalah Youtube, dengan tingkat penetrasi lebih dari $88 \%$, namun demikian, semua platform media sosial lainnya yang dikenal luas seperti WhatsApp dan Facebook, juga berada pada tingkat penetrasi yang tinggi. Kondisi inilah yang menjadikan Indonesia menjadi pasar media sosial dalam kategori besar. Perlu disadari bahwa fakta meningkatnya jumlah pengguna internet dan meningkatnya keterjangkauan smartphone telah berhasil mengubah lingkungan media sosial di Indonesia.

Kalangan milenial memang menggunakannya dan hampir pada semua hal untuk menjadikan dan membuat hidup mereka lebih mudah. Gaya kalangan milenial menginginkan sesuatu yang serba instan. Bagi sebagian besar orang Indonesia, melalui media sosial adalah cara yang termudah untuk menghubungi keluarga di lokasi terpencil di kepulauan negeri ini. Hal ini sangat memungkinkan bagi mereka untuk terus berinteraksi dengan teman dan membuat mereka tetap bisa memperoleh berita harian yang lebih current dan up to date. Selanjutnya untuk data penggunaan media sosialnya seperti pada Gambar 3. 


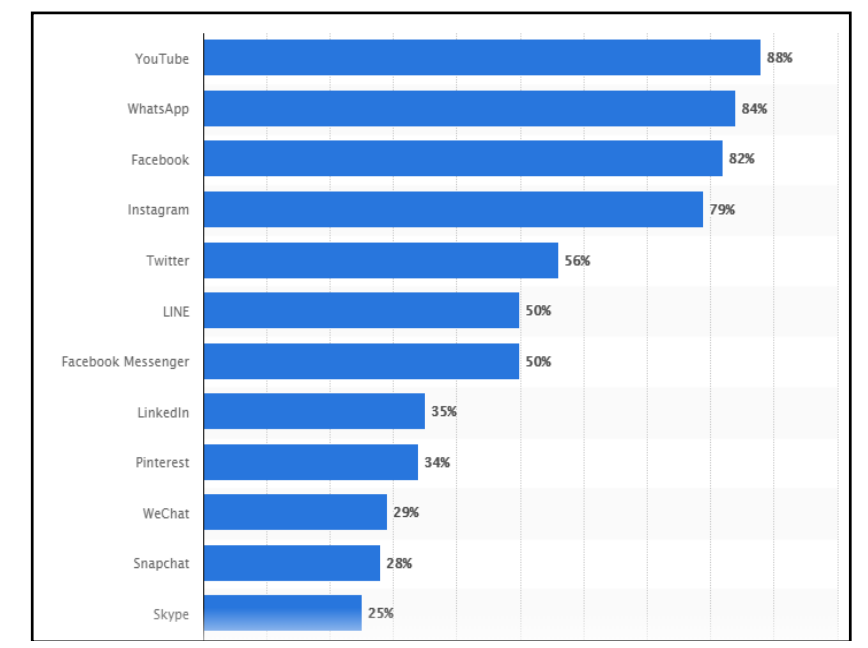

Gambar 3. Penetrasi Jejaring Sosial Kuartal Ketiga 2019

(Sumber: Statisca Research Department)

Dari Gambar 3 nampak bahwa YouTube menempati posisi tertinggi yang digunakan, dibanding dengan aplikasi media sosial lainnya seperti: WhatsApp, Facebook, Instagram, Twitter, LINE, Facebook Messenger, LinkedIn, Pinterest, WeChat, Snapchat, serta Skype. Dari data APJII (2018) disebutkan bahwa Facebook adalah data konten internet yang tersering dikunjungi (45,3\%). Hal ini berarti tahun 2020, Facebook telah tergeser penggunaannya, dibanding dengan WhatsApp dan Youtube yang kini justru banyak digandrungi.

Majunya penggunaan media sosial juga diiringi perilaku negatif, sehingga muncul cybercrime maupun hacker. Akhirnya seperti yang saat ini terjadi bahwa Indonesia juga sangat rentan terhadap tipuan online. Pemerintah melalui instansi terkait juga sudah tegas menindak dan membuat kebijakan maupun regulasi yang mengatur hal ini. Suatu contoh pada tahun 2019, setelah kerusuhan Pilpres 2019, pemerintah membatasi sebagian akses ke platform media sosial paling populer untuk menjaga keamanan nasional dengan menangkal persebaram kabar bohong, hoaks, dan konten negatif. Langkah ini sebagai upaya mencegah dan menghentikan penyebaran berita palsu. Laporan NetBlock.org dalam www.cnbcindonesia.com, bahwa media sosial yang terkena dampak dibatasi aksesnya adalah Facebook, Facebook Messenger, WhatsApp, Instagram, maupun Telegram (Franedya, 2019).

\section{PENUTUP}

\section{KESIMPULAN}

Aplikasi yang tersedia di media sosial sangat terkait dengan smartphone yang lekat dengan kalangan milenial. Media sosial memungkinkan adanya hiperaktualitas, hiperaktivitas, maupun interaktivitas tanpa batasan ruang dan waktu, selain hoaks, kejahatan juga muncul seiring berkembangnya teknologi sehingga pesan moral bagi kalangan milenial adalah wajib hukumnya untuk membekali diri dengan kompetensi literasi digital, kecerdasan intelektual, maupun memahami produk hukum. Keberadaan berbagai informasi hoaks yang berkelindan dimedia sosial itu sengaja dilakukan oleh oknum. Hal ini merupakan modus operandi untuk membangun mesin viralisasi dan dilakukan secara terstruktur dan sistematis. 


\section{SARAN}

Dalam konteks ini, berarti perlu langkah antisipatif penegakan hukum sehingga bukan berarti kalangan milenial sebagai pengguna media sosial kemudian bisa sebebas-bebasnya berkomentar dan melakukan apa saja di media sosial. Ada yang mengintai dan mengawasi sehingga kalangan milenial harus hati-hati jangan sampai masuk dalam permainan dan perangkap oknum tersebut. Kebebasan informasi kalangan milenial harus dibarengi dengan sikap bijak dalam bermedia sosial. Untuk peneliti selanjutnya dapat membuat kajian/penelitian yang berkaitan dengan penggunaan media sosial bagi remaja berdasarkan gender dimasa pandemi covid-19, sehingga subjek penelitian lebih fokus dan pembahasan yang lebih menyeluruh serta dapat mencapai kebaruan kajian/penelitian.

\section{DAFTAR PUSTAKA}

Asosiasi Penyelenggara Jasa Internet Indonesia. (2018). Laporan Survei Penetrasi \& Perilaku Pengguna Internet Indonesia, Survei APJII 2018.

Brine, A. (2009). Handbook of Library Training Practice and Development. London and New York: Routledge Taylor \& Francis Group.

Data Reportal. (2020). Digital 2020. July Global Statshot Report. Tersedia di https:/www.slideshare.net/DataReportal/digital-2020-july-global-statshot-report-july2020-v01?next slideshow $=1$.

Data Reportal. (2020). Digital 2020: Global Digital Overview. Tersedia di https://datareportal.com/reports/digital-2020-global-digital-overview.

Data Reportal. (2020). Digital 2020: Indonesia. Tersedia di https://datareportal.com/reports/digital-2020-indonesia.

Dijk, J.V. (2006). The Network Society. London: Sage Publication.

Franedya, Roy. (2019). Facebook Sampai WhatsApp, Ini Medsos yang Diblokir di RI.

Tersedia di Https://www.cnbcindonesia.com/tech/20190524112724-37-74819/facebooksampai-whatsapp-ini-medsos-yang-diblokir-di-ri.

Gallacher, C.A. (1999). Managing Change in Libraries and Information Services. London: Aslib.

Haryatmoko. (2016). Membongkar Rezim Kepastian: Pemikiran Kritis Post-Strukturalis. Yogyakarta: Kanisius.

Holmes, D. (2005). Communication Theory: Media, Technology, Society. London: Sage Publication.

JAKPAT.NET (2017). Indonesia Mobile Habit Report Q1 2017. Tersedia di https://blog.jakpat.net/indonesia-mobile-habit-report-q1-2017/.

JAKPAT.NET. (2019) Indonesian Mobile Habit (2019). JAKPAT Special Report - $2^{\text {nd }}$ Semester of 2019. Tersedia di https://blog.jakpat.net/indonesian-mobile-habit-2ndsemester-of-2019-jakpat-survey-report/.

JAKPAT.NET. (2019). Indonesia Social Media Trend 2nd Semester of 2019. Diakses melalui https://jakpat.net/pdf/22851/indonesia-social-media-trend-2nd-semester-of-2019--jakpat-survey-report-free-version.

Jones, C. and Shao, B. (2011). The Net Generation and Digital Natives: Implications for Higher Education: A Literature Review Commissioned by the Higher Education Academy. https://www.heacademy.ac.uk/system/files/next-generation-and-digitalnatives.pdf. 
Pemerintah Indonesia. Undang-Undang Republik Indonesia Nomor 14 Tahun 2008 Tentang Keterbukaan Informasi Publik. Jakarta: Sekretariat Negara.

Pemerintah Indonesia. Undang-Undang Republik Indonesia Nomor 19 Tahun 2016 Tentang Perubahan Atas Undang-Undang Republik Indonesia Nomor 11 Tahun 2011 Tentang Informasi dan Transaksi Elektronik. Jakarta: Sekretariat Negara.

Statisca Research Department. (2019). Indonesia Social Network Penetration. Tersedia di www.statista.com/statistics/284437/indonesia-social-network-penetration.

Statisca Research Department. (2019). Penetration of leading social networks in Indonesia as of 3rd quarter 2019. Tersedia di https://www.statista.com/statistics/284437/indonesiasocial-network-penetration/.

Tapscott, D. (2009). Grown Up Digital: How The Net Generations is Changing Your World. New York: McGraw-Hill.

Thompson, J.A., Strickland, A.J, and Gamble, E.J. (2010). Crafting and Executing Strategy. New York: McGraw Hill.

Young, K. (1998). Caught in the Net: How to Recognize the Signs of Internet Addiction and a Winning Strategy for Recovery. New York: Wiley. 